\title{
Juridic Problematics Management of Social Support Institutions (Case Study at Al Washliyah Ormas)
}

\author{
Haidir*, Ismed Batubara, Yopiza, Muhammad Hizbullah, and Yeltriana \\ Universitas Muslim Nusantara Al Washliyah Medan, Indonesia \\ *Corresponding author email: haidir@umnaw.ac.id
}

\begin{abstract}
Al-Washliyah organization was founded on 30 November 1930 in Medan City. Al-Jam'iyatul Washliyah was successfully born based on the idea, the thoughts of the highest-class students at MIT (Maktab Islamiyah Tapanuli) who were extraordinarily intelligent, who initially formed an association called the Debating Club led by Abdurrahman Syihab. The founders were Ismail Banda, Abdurrahman Sjihab, Arsjad Thalib Lubis, Adnan Nur, H. M. Yacub, H. Sjamsuddin, H. Yusuf Ahmad Lubis and H. Abdul Malik, Abd. Aziz Effendy. This is in accordance with the al-Washliyah organization's ittifaq charity, namely education, preaching and social society. As for the problem in this research is how the juridical problems faced by Al-Washliyah in the management of the orphanage and how the efforts made so that the juridical problems can be resolved properly. The research method used is a normative juridical research method which is based on secondary legal materials only in the form of books and research results that have been tested and are valid. The purpose of this study was to determine the juridical problems faced by Al-Washliyah and what efforts were made to solve them. The conclusion obtained from this research is that the juridical problem is the need for a clear regulation of legal relations in the AD/ART of Al-Jam'iyatul Washliyah regarding the legal relationship between PB Al-Washliyah and the Orphanage Foundation administrators to make clearer rights and obligations and authority of both parties.
\end{abstract}

\section{Keywords: Orphanage, Al-Washliyah, Problematics, Juridical}

\section{INTRODUCTION}

Islamic social organizations (ormas) have a significant role in the struggle of the Indonesian nation by devoting their time, energy and thoughts in various fields, such as education, preaching, health and social society [1], and Islamic organizations in North Sumatra are no exception. Machmudi [2] completely captures the history and profiles of 14 (fourteen) Islamic organizations, including: Sarekat Islam, Muhammadiyah, Al Irsyad, Mathlaul Anwar, Islamic Association, Nahdlatul Ulama, Rabithah Alawiyah, Al-Jam'iyatul Washliyah, Al Ittihadiyah, Muslim Ummah Association, Nadhlatul Wathan, Indonesian Islamic Da'wah Council, Indonesian Ulama Council and the Indonesian Muslim Intellectuals Association.
The contribution of Islamic organizations is quite large in the history of the struggle of the Indonesian nation, both on a local and national scale [3]-[5].

The history of Islamic mass organizations is very long. They have been present across various eras, from the era of Dutch colonialism, Japanese colonialism, postindependence, the old order, the new order and the reformation era until now. In the trajectory of the changing times, one thing is certain, namely that these Islamic organizations have made a very large contribution not only to the interests of education, preaching, health and social support for the Muslims, but also in raising and maintaining social activities, the spirit of Islam and to Indonesia, and filling independence for the benefit of the dignity of the state and nation of Indonesia [6]-[9]. 
One of the Islamic organizations is Al-Jam'iyatul Washliyah. On November 30, 1930 with the birth of AlJam'iyatul Washliyah in Medan on the basis of Islam, with the law of fiqh which translates into Syafi'i and iktikad following the establishment of Ahlus sunnah wa'l jama'ah. The leaders included: Ismail Banda, Abdurrahman Sjihab, Arsjad Thalib Lubis, Adnan Nur, H.M. Yacub, H. Sjamsuddin, H. Yusuf Ahmad Lubis and H. Abdul Malik, Abd. Aziz Effendy and Muhammad Nurdin (Nukman Sulaiman, 1956). Al-Jam'iyatul Washliyah was born from the thinking of the highest-grade students at MIT who were intelligent who formed a Debating Club led by Abdurrahman Syihab [10]-[12].

Since its birth, this organization has synergized its three main charities or iitifaq charities simultaneously, namely education, da'wah and social affairs, represented by the establishment of orphanages in several areas [13]-[16]. The study, which is relatively not elaborated by many researchers, is about the existence of the Al Washliyah Orphanage. It is interesting to study because since 19341951 Al-Jam'iyatul Washliyah has owned 7 (seven) orphanages, consisting of four Al-Jam'iyatul Washliyah orphanages in Medan, one unit in Binjai, one unit in Lubuk Pakam, one unit in Tanjung Balai, and one unit in Rantau [17].

Al-Jam'iyatul Washliyah as a mass organization has characteristics like other mass organizations, namely selfregulating and self-financing [18]-[20]. Self regulating means self-regulation and self-financing means independent funding. So, the management of its ittifaq charity requires professional management so that the noble goals desired can be achieved, including the management of the orphanage. Several facts portray serious juridical problems between the orphanage administrators and the Al-Jam'iyatul Washliyah board in managing the orphanage [21].

Based on the explanation above, the problem formulations that have been determined are as follows. What are the actual juridical problems faced by Al-Jam'iyatul Washliyah in managing the orphanage? How are the efforts made so that these juridical problems can be resolved properly?

The purpose of this research to determine the juridical problems in the management of the Al-Jam'iyatul Washliyah Orphanage. And to find out the efforts made so that these juridical problems can be resolved.

\section{METHODOLOGY}

The research location is in the city of Medan because the area/city that has the most number of Al-Jam'iyatul Washliyah Orphanages, namely four orphanages.

Type of research. The method used in this research is normative legal research method. Normative legal research is also called literature law research because legal research is carried out by examining library materials or secondary data (Soerjono Soekanto, 1983).

Types and Sources of Data. Based on the definition of normative legal research, primary data is not needed, only secondary data is needed. Secondary data consists of

a. primary legal materials are legal materials that are authoritative in nature, means having authority [22][23];

b. secondary legal materials, namely materials that provide an explanation of primary legal materials, such as the Draft Law, research results and research relevant to the research;

c. tertiary legal materials are materials that provide instructions and explanations for primary and secondary legal materials in the form of general dictionaries, legal dictionaries, magazines, newspapers and legal journals, scientific reports

\section{RESULTS AND DISCUSSION}

Based on the research results that the foundation made by the organization Al-Jam'iyatul Washliyah in the care of the orphan is a philosophical foundation. Namely AlJam'iyatul Washliyah in caring for orphans is to use the commands of the Qur'an and Hadith. Al-Qur'an ordered to care for orphans in accordance with the letter Al Maun. This verse states about the obligation of Muslims and Muslims to care for and support children who are orphans and the poor and if they do not want to be considered liars of Islam. In one verse it is also stated which means: "If you help Allah's religion, surely Allah will help you". In one of the Hadiths, it is also stated that the guardian of orphans will be close to the Messenger of Allah in Heaven.

a. Al-Jam'iyatul Washliyah first opened an orphanage madrasa on April 1, 1934 at one of the Al-Jam'iyatul Washliyah Madrasas next to Mesjid Raya Medan, under the leadership of M. Nurdin [17]. A year later, the Al-Jam'iyatul Washliyah Orphanage was established [24]. The Al-Jam'iyatul Washliyah orphanage that currently still exists is as presented ini Table 1 [25].

b. Terms and conditions for being a child at an orphanage: muslim, orphans, orphanage, poor/neglected children, 13 years old, certificate from the village head, and family card

Based on an interview with Mr. H. Yusrok, S.Ag [26] who sent his nephew to the Al-Jam'iyatul Washliyah Orphanage in Pulo Brayan. He said that at this time most of the residents of the children's homes came from underprivileged or poor children who still had parents who were no longer orphans. 
Table 1 The Al-Jam'iyatul Washliyah Orphanage

\begin{tabular}{|c|c|c|c|}
\hline No & Name & Address & Information \\
\hline 1. & Orphanage Ismailiyah St. No. 82 & Medan & Founded on April 15, 1934 \\
\hline 2. & $\begin{array}{l}\text { Orphanage Al-Jam'iyatul Washliyah, } \\
\text { Yos Sudarso St. Pulo Brayan }\end{array}$ & Medan & $\begin{array}{l}\text { Founded on May } 16,1935 \text { and in } 1940 \text {, the Al- } \\
\text { Jam'iyatul Washliyah Tj. Balai Orphanage was united } \\
\text { with the Pulo Brayan Orphanage. Likewise, the Rantau } \\
\text { Prapat Orphanage which was united with the Pulo } \\
\text { Brayan Orphanage in } 1950 .\end{array}$ \\
\hline 3. & $\begin{array}{l}\text { Al-Jam'iyatul Washliyah Orphanage, } \\
\text { Lalang Village, Pinang Baris }\end{array}$ & Medan & Founded in 1943 \\
\hline 4. & $\begin{array}{l}\text { Al-Jam'iyatul Washliyah Orphanage, } \\
\text { Johor Building }\end{array}$ & Medan & Founded in 1969 \\
\hline 5. & $\begin{array}{l}\text { Al-Jam'iyatul Washliyah Lubuk Pakam } \\
\text { Orphanage }\end{array}$ & Lubuk Pakam & Founded on May 5, 1946 \\
\hline 5. & $\begin{array}{l}\text { Al-Jam'iyatul Washliyah Orphanage Jl. } \\
\text { Srikandi Diniyah }\end{array}$ & Binjai & Founded in 1942 \\
\hline 6. & $\begin{array}{l}\text { Al-Jam'iyatul Washliyah Orphanage, } \\
\text { Tanjung Pura }\end{array}$ & Tanjung Pura & Founded in 1955 \\
\hline 7. & $\begin{array}{l}\text { Al-Jam'iyatul Washliyah Tj. Balai } \\
\text { Orphanage }\end{array}$ & Tj. Balai & $\begin{array}{l}\text { Founded on October 1946, now has stood the New } \\
\text { Building at the PD Al-Jam'iyatul Washliyah Tj. Hall }\end{array}$ \\
\hline 8. & Al Arif Orphanage & Rantau Prapat & Founded on July 17,2000 \\
\hline 9. & $\begin{array}{l}\text { Al-Jam'iyatul Washliyah Orphanage } \\
\text { Gunung Sitoli }\end{array}$ & Gunung Sitoli & Not found valid data \\
\hline 10. & $\begin{array}{l}\text { Panti Asuhan Al-Jam'iyatul Washliyah } \\
\text { Lam Ujong } \\
\text { Al-Jam'iyatul Washliyah Lam Ujong } \\
\text { Orphanage }\end{array}$ & Aceh Besar & $\begin{array}{l}\text { Founded in } 2007 \text { with the assistance of Sinyo End and } \\
\text { JICC Japan. Previously this orphanage was located in } \\
\text { Alua Naga Village, founded in 2003, but was hit by the } \\
2006 \text { Tsunami and was destroyed. Currently occupies a } \\
\text { permanent building on the land of STKIP Al-Jam'iyatul } \\
\text { Washliyah Banda Aceh. }\end{array}$ \\
\hline 11 & Tunas Bangsa Orphanage & Bali & 2006 \\
\hline
\end{tabular}

\subsection{Results}

Case 1. In 1974, the Al-Jam'iyatul Washliyah Central Executive meant the Al-Jam'iyatul Washliyah Grand Board organized the Orphanage. The manager of an orphanage in Medan refuses to accept instructions from the central leadership. He was able to do this because the orphanage that he managed did not belong to $\mathrm{Al}$ Jam'iyatul Washliyah, but belonged to a foundation under the name Al-Jam'iyatul Washliyah. According to the law, he is not authorized to own, own, or control the orphanage. This dispute was finally resolved through the district/city courts, which won the foundation. In this case, the court only suggested that if Al-Jam'iyatul Washliyah objected to the Central Executive prohibiting the foundation from using the name Al-Jam'iyatul Washliyah [21].

Once the Al-Jam'iyatul Washliyah Regional Management sent someone to ask for data on the orphanage, namely the Al-Jam'iyatul Washliyah Orphanage which is located on Jalan Pinang Baris, one of the administrators lightly replied, "we have no relationship with Al Washliyah. We only coordinate with social agencies [27]. This reflects the board of the orphanage who is not responsible to the AlJam'iyatul Washliyah organization.

Case 2. Whereas based on notarial deed No. 67/1955 all leaders of the Al-Jam'iyatul Washliyah Orphanage consisting of the Al-Jam'iyatul Washliyah Pulo Brayan Orphanage, the Al-Jam'iyatul Washliyah Johor Building Orphanage, Al-Jam'iyatul Washliyah Pinang Baris Orphanage, and the Al-Jam'iyatul Washliyah Orphanage in Tanjung Pura were appointed and dismissed by the General Chairperson of the Al-Jam'iyatul Washliyah Charity and Social Foundation, which at that time was chaired by H. Muhammad Nurdin from 1955-1985 and then continued to change with Other management and foundation deeds have been renewed with the new Foundation Law No. 28 of 2004 with the legality of the Decree of the Director General of Legal and General Administration No. AHU-AH.01.08-437 dated 27 July 2009.

So, since Wednesday, April 28, 2010 there has been a dualism of leadership at the Pulo Brayan Al-Jam'iyatul Washliyah Orphanage, namely Hamzah who was appointed by the Regional Board of Al-Jam'iyatul Washliyah Medan City and Ustadz H. Khairuddin, Lc. who was appointed by the Management Foundation [28]. It was only a few years later that this dualism of leadership ended when H. Darius, SH, MH, was appointed as the Head of the Al-Jam'iyatul Washliyah Orphanage in Pulo Brayan. 
Case 3. Al-Jam'iyatul Washliyah Orphanage, Johor Building, there has been a lot of debate about who has the right to manage the orphanage but its leader at that time was Hj. Rodiah Manjorang loudly answered: "The AlJam'iyatul Washliyah Orphanage has no connection with the Al-Jam'iyatul Washliyah Executive Board because since the establishment of this orphanage until now without any assistance from PB Al-Jam'iyatul Washliyah and we have certificate of establishment of a legal orphanage.

\subsection{Analysis}

Based on the cases above, it can be found that the juridical problems in the management of the Al-Jam'iyatul Washliyah Orphanage are due to the absence of regulations in Al-Jam'iyatul Washliyah's Basic Articles/Bylaws regarding the legal relationship between the Executive Board and the Foundation Management that manages the Orphanage Al Washliyah. So, the effort made so that these juridical problems can be resolved properly and correctly is to make clear arrangements in the AD/ART of Al-Jam'iyatul Washliyah regarding the legal relationship between the Executive Board and the Al-Jam'iyatul Washliyah Orphanage Foundation so that there is no gap. as was done by the Orphanage Administrators by making their own notaries with No. $67 / 1955$ which was vulnerable to giving answers to the management that the foundation had no relationship with Al-Jam'iyatul Washliyah. This has legally fatal consequences regarding the management of the $\mathrm{Al}$ Jam'iyatul Washliyah Orphanage, such as in the Johor Building which did not accept the policy of the Grand Board and the Al-Jam'iyatul Washliyah Orphanage Jl. Pinang Baris which disputed the Medan District Court with the Grand Management, and the dualism of management as happened at the Pulo Brayan Orphanage.

\section{CONCLUSION}

Based on the analysis of cases that occurred in the relationship between the Executive Board and the Board of the Al-Jam'iyatul Washliyah Orphanage Foundation, it can be concluded as follows.

1. Clear arrangement regarding the legal relationship between the Executive Board and the Al-Jam'iyatul Washliyah Orphanage is very urgent by looking at the history of disputes between the Al-Jam'iyatul Washliyah Orphanage and the Executive Board in the case of the Al-Jam'iyatul Washliyah Orphanage located at Jl. Pinang Baris 1974, Pulo Brayan, and Johor Building.

2. With a clear legal relationship, it is also clear that the rights, obligations and authorities between the $\mathrm{Al}$ Jam'iyatul Washliyah Board of Directors and the AlJam'iyatul Washliyah Orphanage in terms of managing the orphanage.
The suggestions to consider are as follows.

1. PB Al-Jam'iyatul Washliyah and its staff under such as the Regional Administrators and Regional Administrators record the existence of orphanages in their respective territories, specifically on its legality aspects.

2. PB Al-Jam'iyatul Washliyah is expected to establish a Dispute Resolution, Organizational Rescue (LP30) institution that is registered with the Ministry of Justice and Human Rights so that organizational problems can be resolved by deliberation and consensus so as not to reach the Court and not cause conflict in the community.

\section{REFERENCES}

[1] F. Said, Peranan Ulama dalam merebut dan mengisi Kemerdekaan RI. Medan: Pustaka Babussalam, 1998.

[2] Y. Machmudi, Sejarah dan Profil Ormas-ormas Islam di Indonesia. Pusat Kajian Timur Tengah dan Islam Universitas Indonesia, 2013.

[3] H. Basri, A. K. S. Nabiha, M. S. A. Majid, Accounting and Accountability in Religious Organizations: An Islamic Contemporary Scholars' Perspective. Gadjah Mada International Journal of Business, 18 (2) (2016), 207-230.

[4] B. Cahya, A. Nuruddin, A. Ikhsan, Islamic Social Reporting: From the Perspectives of Corporate Governance Strength, Media Exposure and the Characteristics of Sharia Based Companies in Indonesia and its Impact on Firm Value. IOSR Journal of Humanities and Social Science, 22 (5) (2017), 71-78.

[5] F. Darus, N. H. A. Shukri, H. Yusoff, A. Ramli, M. M. Zain, N. A. A. Bakar, Empowering social responsibility of Islamic organizations through Waqf. Research in International Business and Finance, 42 (2017), 959-965.

[6] M. Peucker, R. Ceylan, Muslim community organizations - sites of active citizenship or selfsegregation?. Ethnic and Racial Studies, 40 (14) (2017), 2405-2425.

[7] P. C. Saidalavi, Muslim Social Organisation and Cultural Islamisation in Malabar. South Asia Research, 37 (1) (2017), 19-36.

[8] L. M. Ifada, I. Ghozali, F. Faisal, Islamic Organizational Culture, Islamic Corporate Social Responsibility, and Corporate Performance: Evidence from Sharia Bank in Indonesia. International Journal of Financial Research, 10 (6) (2019), 118-123. 
[9] R. Eseed, Social Service Provision by Minority Religious Organizations: A Case Study of the Islamic Movement in Kafr Qassim. Journal of Social Policy, 49 (3) (2020), 507-524.

[10] N. Sulaiman, Peringatan $1 / 4$ abad Al Washliyah. Medan: PB Al Washliyah, 1956.

[11] Ja'far, Ideologi Al Jam'iyatul Washliyah. Yogyakarta: K-Media, 2019.

[12] M. Tanjung, Maktab Islamiyah Tapanuli Menelusuri Sejarah Pendidikan Islam Awal Abad ke-20 di Medan. Medan: Kerjasama Perdana Publishing dan Majelis Pendidikan Tinggi PB Al Washliyah, 2020.

[13] A. Saragih, Kontribusi Al Jam'iyatul Washliyah terhadap Kemerdekaan Indonesia (1930-1950). MIQOT, 15 (1) (2016), 142-161.

[14] M. Rozali, Tradisi Dakwa Ulama Al Jam'iyatul Washliyah Sumatera Utara. Jurnal Al-Bayan, 22 (33) (2016), 62-81.

[15] J. Ja'far, Peran Al Jam'iyatul Washliyah dalam Merevitalisasi Madhhab Shafi'i di Era Kontemporer. Justicia Islamica, 13 (1) (2016), 1-21.

[16] J. Ja'far, Khazanah Kitab Kuning di Madrasah Al Jam'iyat Al Washliyah. Jurnal Pendidikan Agama Islam Al-Thariqah, 2 (2) (2017), 124-134.

[17] M. Nurdin, Riwayat Ringkas dan Penjelasan Majelis Anak Miskin dan Yatim Piatu dalam Husein Abd. Karim, dkk. Pustaka Al Washliyah, 1951.

[18] Ja'far, Al Jam'iyatul Washliyah dan Problem Kepemimpinan Non-Muslim dan Perempuan. AHKAM, 17 (2) (2017), 413-434.

[19] Ja'far, Respons Al Jam'iyatul Washliyah terhadap Terorisme. AKADEMIKA Jurnal Pemikiran Islam 22 (1) (2017), 1-26.

[20] L. Hanum, Perempuan di Lembaga Pendidikan Al Jam'iyatul Washliyah. Journal of Contemporary Islam and Muslim Societies, 2 (1) (2018), 29-49.

[21] U. Pelly, Urbanisasi dan Adaptasi Peranan Misi Budaya Minangkabau dan Mandailing. Jakarta: LP3ES, 1994.

[22] J. Suprapto, Metode Penelitian Hukum dan Statistik. Jakarta: Rineke Cipta, 2003

[23] P. M. Marzuki, Penelitian Hukum Normatif. Jakarta: Kencana, 2008.
[24] M. B. Nasution, Kewenangan Bertindak Pengurus dan Pertanggung Jawaban Yayasan Amal Sosial AlJam'iyatul Washliyah Jl. Ismailiyah No. 82. Skripsi. Fakultas Hukum, Universitas Al Washliyah, Medan, 2005.

[25] I. Batubara, Dinamika Pergerakan Al-Jam'iyatul Washliyah Zaman Ber Zaman. Medan: Kerjasama Perdana Publishing dan Majelis Pendidikan Tinggi PB Al Washliyah, 2020.

[26] H. Yusrok, S.Ag., Wawancara pada Kamis, 12 November 2020.

[27] I. Batubara, Peran Al-Jam'iyatul Washliyah dalam pemeliharaan Anak Yatim Piatu. Jurnal Kalam Keadilan, 2 (2) (2013).

[28] D. S. Lase, Efektifitas Pelayanan Sosial Anak di Bidang Pendidikan oleh Panti Asuhan Yayasan Amalsosial Al-washliyah Kelurahan Gedung Johor Kecamatan Medan Johor. Welfare State, 1 (1) (2012), 9 pages. 